\title{
Review: Mycoendophytes in medicinal plants: Diversity and bioactivities
}

\author{
MAHENDRA RAI ${ }^{1, \bullet}$, ANIKET GADE ${ }^{1}$, DNYANESHWAR RATHOD ${ }^{1}$, MUDASIR DAR $^{1}$, AJIT VARMA ${ }^{2}$ \\ ${ }^{1}$ Department of Biotechnology, Sant Gadge Baba Amravati University, Amravati-444602, Maharashtra India. Tel: +91-721-2662206 to 8, Fax: +91-721- \\ 2662135, 2660949, `email: mkrai123@ rediffmail.com \\ ${ }^{2}$ Amity Institute of Microbial Technology, Amity University, Sector 125, Noida, Uttar Pradesh, India
}

Manuscript received: 23 June 2012. Revision accepted: 16 July 2012.

\begin{abstract}
Rai M, Gade A, Rathod D, Dar M, Varma A. 2012. Review: Mycoendophytes in medicinal plants: Diversity and bioactivities. Nusantara Bioscience 4: 86-96. Endophytes are microorganisms that reside in internal tissues of living plants without causing any negative effect. These offer tremendous potential for the exploitation of novel and eco-friendly secondary metabolites used in medicine, the pharmaceutical industry and agriculture. The present review is focused on diversity of endophytes, current national and international bioactive secondary metabolite scenario and future prospects. Endophytic fungi as novel source of potentially useful medicinal compounds are discussed along with the need to search for new and more effective agents from endophytes to combat disease problems
\end{abstract}

Keywords: fungal diversity, mycoendophyte, medicinal plants, secondary metabolites.

\begin{abstract}
Abstrak. Rai M, Gade A, Rathod D, Dar M, Varma A. 2012. Review: Mikoendofit pada tumbuhan obat: Keanekaragaman dan bioaktivitasnya. Nusantara Bioscience 4: 86-96. Endofit adalah mikroorganisme yang tinggal di dalam jaringan internal tumbuhan hidup tanpa menimbulkan efek negatif. Hal ini berpotensi sangat besar untuk menghasilkan metabolit sekunder baru dan ramah lingkungan yang digunakan dalam bidang kedokteran, industri farmasi dan pertanian. Ulasan ini difokuskan pada keanekaragaman endofit, perkiraan kebutuhan bioaktif metabolit sekunder secara nasional dan internasional pada saat ini dan prospeknya di masa depan. Fungi endofit sebagai sumber baru senyawa obat potensial berguna dibahas bersama dengan perlunya menemukan agen endofit baru dan lebih efektif untuk memerangi masalah penyakit.
\end{abstract}

Kata kunci: keanekaragaman fungi, mikoendofit, tumbuhan obat, metabolit sekunder

\section{INTRODUCTION}

Endophytes are microbes (fungi or bacteria) that live within the plant tissues without causing any noticeable symptoms of disease (Tejesvi et al. 2007). We propose a new term "Mycoendophytes" for fungi living as endophytes in plants. According to Rodriguez et al. (2009) endophytes are classified into four classes. Class 1 endophytes are clavicipitaceous while class 2-4 are nonclavicipitaceous. Class 1 endophytes of grasses were first reported by European investigators in the late $19^{\text {th }}$ century in seeds of Lolium temulentum, L. arvense, L. linicolum and L. remotum. From their first finding, investigators hypothesized that an association to toxic syndromes experienced by animals that consume infected tissues. However, these hypotheses were largely untested until Bacon et al. (1977) linked the endophyte Neotyphodium coenophialum to the widespread occurrence of 'summer syndrome' toxicosis in cattle grazing tall fescue (Festuca arundinaceae) pastures. Class 2-4 which includes nonclavicipitaceous endophytes, showed the ability to colonize asymptomatically and confer habitat-adapting fitness benefits on genetically distant host species that may include both monocots and dicots. Most of these fungal endophytes belong to Ascomycota, with a marginal of Basidiomycota. Class 2 endophytes within the Basidiomycota are members of the Agaricomycotina and Pucciniomycotina. Class 2 endophytes are dissimilar from the previous nonclavicipitaceous (NC) endophytes; because in general, they colonize roots, stems and leaves and are capable of forming extensive infections within plants. Class 2 endophytes are transmitted via seed coats and or rhizomes; having low abundance in the rhizosphere Class 2 endophytes have conferred habitat-adapted fitness benefits in addition to non-habitat-adapted benefits, and typically have high infection frequencies (90-100\%) in plants growing in highstress habitats (Rodriguez et al. 2009). Class 3 endophytes comprise the hyperdiverse endophytic fungi associated with leaves of tropical trees, moreover the highly diverse associates of above-ground tissues of nonvascular plants, seedless vascular plants, conifers, and woody and herbaceous angiosperms in biomes ranging from tropical forests to boreal and Arctic/Antarctic communities (Rodriguez et al. 2009). Class 4 endophytes are mainly ascomycetous fungi that are conidial or sterile and that form melanized structures such as inter- and intracellular hyphae and microsclerotia in the roots (Rodriguez et al. 2009). 
Mycoendophytes have been found in healthy tissues of all the plant taxa studied to date. Endophytes invade the tissues of living plants and reside in the tissues between living plant cells (Vanessa and Christopher 2004). Some form a mutually beneficial relationship (symbiosis) with the host plants while others are opportunistic pathogens. Petrini et al. (1992) reported that there may be more than one type of mycoendophytes found within a single plant. For example, thirteen taxa of mycoendophyte were isolated from the leaf, stem and root tissues of Catharanthus roseus (Kharwar et al. 2008)

Herre et al. (2007) demonstrated that mycoendophyte plays potentially important mutualistic role by augmenting host defense response against pathogens. Endophytes may contribute to host protection by increasing the expression of intrinsic host defense mechanisms and or providing additional sources of defense extrinsic to those of the host. There has been immense interest in the prospecting for these microbial endophytes as source of novel bioactive natural products. Endophytes do show much chemical diversity: alkaloids, peptides, steroids, terpenoids, isocoumarins, quinones, phenylpropanoids, lignans, phenols, phenolic acids, aliphatic compounds, lactones, and others. After the discovery of taxol produced by Taxomyces andreanae from Taxus brevifolia, interest in endophyte research has increased at a fast pace. T. brevifolia is a member of family Taxaceae and native to the north-western United States. The natural product of T. brevifolia taxol has been used in the treatment of cancer treatments. Isolation of taxol from Pestalotiopsis microspora, an endophyte of Taxus wallichiana and phytohormone gibberellin from Gibberella fujikuroi in rice plants underlines the potential of endophytes as a source of useful metabolites (Gehlot et al. 2008). The screening of microbial culture filtrates for the presence of secondary metabolites is an established method for the identification of biologically active molecules (Hamayun et al. 2009).

\section{DIVERSITY OF MYCOENDOPHYTES}

Mycoendophytes are the most frequent endophytes isolated from medicinal plants. Dreyfuss and Chapela (1994) estimated that there may be at least 1 million species of mycoendophytes. Shipunov et al. (2008) tested the co-introduction and host-jumping hypotheses in plant communities by comparing endophytes isolated from the invasive spotted knapweed (Centaurea stoebe, Asteraceae) in its native and invaded ranges. Shipunov and his group (2008) indicated that endophytes can affect the competitiveness of $C$. stoebe. As both co-introduction and host-jumping of endophytes align with hypotheses of plant invasion that are based on enhanced competitiveness. Kharwar et al. (2008) reported 183 mycoendophytes representing 13 fungal taxa isolated from leaf, stem and root tissues of $C$. roseus from two sites representing two different ecosystems in North India. The leaf tissues showed more diversity of endophytes like Drechslera, Curvularia, Bipolaris, Alternaria and Aspergillus spp. Wei et al. (2009) studied the colonization frequencies of endophytic Pestalotiopsis species diverse with host plants, ages, tissues, and sites. Lv et al. (2010) reported 49 endophytic fungi which were recovered from Saussurea involucrata and identified using morphological and molecular techniques. Among theses fungi, Cylindrocarpon sp. was the dominant species followed by Phoma sp. and Fusarium species. Li and Shun (2009) reported the recovery of 300 isolates in which 172 isolates were from Dracaena cambodiana and 128 from Aquilaria sinensis. Proksch et al. (2009) reported bioactive marine natural products isolated from marine sponges and marine-derived fungi.

The maximum biological diversity in terrestrial ecosystems is in tropical and temperate rainforests; interestingly, they also have the greatest number of mycoendophytes. These ecosystems cover only $1.44 \%$ of the land's surface, yet they harbor more than $60 \%$ of the world's terrestrial biodiversity (Strobel and Daisy 2003). Hazalin et al. (2009) isolated 300 endophytes from various parts of plants collected from the National Park, Penang in Malaysia. Some of these endophytes demonstrated cytotoxic activity against the murine leukemic P388 cell line and $1.7 \%$ against a human chronic myeloid leukemia cell line K562 (Hazalin et al. 2009).

Strobel (2002) reported that fungal endophytes residing within plants could also produce metabolites similar to or with more activity than those of their respective hosts. Therefore, the search for novel compounds should be directed towards plants that are used by indigenous populations for medicinal purposes, or plants growing in extreme environments, or those that are endemic. These are most likely to harbor novel endophytes that may produce unique metabolites (Strobel and Daisy 2003; Zhang et al. 2006; Deshmukh and Verekar 2008). Survey of literature provides evidence of increasing research on endophytes and their secondary metabolites. Many endophytes produce important secondary metabolites, which play protective role against insect herbivores or are of industrial importance (Hawksworth et al. 1995; Arnold et al. 2003) (Table 1).

Isolation of endophytic fungi from coffee plants (Coffea arabica and $C$. robusta) was shown to have antimicrobial activity against various human pathogenic bacteria (Sette et al. 2006). Coffea arabica of family Rubiaceae is luxuriantly cultivated in Southern India, Madras, Mysore, Coorg, Travancore, and Cochin. C. arabica is being used as an Analgesic, cardiotonic, CNS stimulant, nervine, stimulant and hypnotic. Large differences have been observed amongst the isolates with respect to their ability to produce metabolites having antimicrobial activity (Pelaez et al. 1998). At present, there is an urgent need to search for endophytic metabolite that can be developed as safe, effective antifungal agents that are non-petrochemical, eco-friendly and easily obtained (Liu et al. 2006).

Bacon et al. (1977) demonstrated the correlation between the presence of the mycoendophyte, Epichloe typhina isolated from Festuca arundinacea (Tall fescue) and the toxicity of its host to herbivorous domestic mammals. Further, they observed that several toxins produced by endophytic fungi and conferred host protection against different herbivores. Mycoendophytes were isolated from the toxic locoweeds Astragalus mollissimus, 
Table 1. Endophytes isolated from different medicinal plants

\begin{tabular}{|c|c|c|c|c|c|}
\hline Endophytes & Host & $\begin{array}{l}\text { Use of plant in traditional } \\
\text { medicinal }\end{array}$ & Location & Bioactivity & Reference \\
\hline Alternaria alternata & $\begin{array}{l}\text { Vitis vinifera } \\
\text { (Grapevine) }\end{array}$ & $\begin{array}{l}\text { Blood circulation, eye } \\
\text { problems }\end{array}$ & Europe & Antifungal & Musetti et al. 2006 \\
\hline $\begin{array}{l}\text { Alternaria sp., } \\
\text { Phoma spp. }\end{array}$ & Opuntia (Cactus species) & Wound healing & America & Antiviral & $\begin{array}{l}\text { Suryanarayanan et } \\
\text { al.2005 }\end{array}$ \\
\hline $\begin{array}{l}\text { Aspergillus flavus, } \\
\text { Phoma sp., } \\
\text { Penicillium }\end{array}$ & $\begin{array}{l}\text { Calotropis procera } \\
\text { (Milkweed, } \\
\text { Rubber bush) }\end{array}$ & $\begin{array}{l}\text { Asthma, leprosy, and in } \\
\text { chronic eczema }\end{array}$ & North Africa & Antimicrobial & Khan et al. 2007 \\
\hline $\begin{array}{l}\text { Botryosphaeria } \\
\text { rhodina }\end{array}$ & $\begin{array}{l}\text { Bidens pilosa } \\
\text { (Spanish needle) }\end{array}$ & $\begin{array}{l}\text { Reduces swelling, headache, } \\
\text { Clears heat and toxins }\end{array}$ & $\begin{array}{l}\text { Tropical } \\
\text { America }\end{array}$ & $\begin{array}{l}\text { Antifungal, } \\
\text { cytotoxic and } \\
\text { antiproliferative }\end{array}$ & Randa et al. 2010 \\
\hline $\begin{array}{l}\text { Colletotrichum } \\
\text { gloeosporioides }\end{array}$ & $\begin{array}{l}\text { Artemisia annua } \\
\text { (Chinese wormwood) }\end{array}$ & Malaria & China & Antimalarial & Tan and Zou 2001 \\
\hline $\begin{array}{l}\text { Colletotrichum sp., } \\
\text { Phyllosticta sp. }\end{array}$ & $\begin{array}{l}\text { Plumeria rubra } \\
\text { (Red Frangipani) }\end{array}$ & $\begin{array}{l}\text { Venereal disease rheumatism, } \\
\text { diarrhea, and leprosy }\end{array}$ & Central America & Antimicrobial & $\begin{array}{l}\text { Suryanarayanan } \\
\text { and Thennarasan } \\
2004\end{array}$ \\
\hline $\begin{array}{l}\text { Colletotrichum } \\
\text { species }\end{array}$ & $\begin{array}{l}\text { Banana, Ginger, } \\
\text { (Jamaica ginger) }\end{array}$ & $\begin{array}{l}\text { Blood, cholesterol thinning, } \\
\text { in heart disease }\end{array}$ & South Asia & Antibacterial & Photita et al. 2005 \\
\hline Curvularia lunata & $\begin{array}{l}\text { Azadirachta indica } \\
(\text { Neem })\end{array}$ & Skin disease diabetic & India & Antifungal & $\begin{array}{l}\text { Verma and } \\
\text { Kharwar } 2006\end{array}$ \\
\hline $\begin{array}{l}\text { Cylindrocarpon sp., } \\
\text { Phoma sp., } \\
\text { Fusarium sp. }\end{array}$ & Saussurea involucrata & $\begin{array}{l}\text { rheumatoid arthritis, cough } \\
\text { with cold, stomachache }\end{array}$ & Asia, Europe & Antimicrobial, anti- & Lv et al. 2010 \\
\hline $\begin{array}{l}\text { Entrophospora } \\
\text { infrequens }\end{array}$ & $\begin{array}{l}\text { Nothapodytes foetida } \\
\text { (Stinking tree) }\end{array}$ & Cancer & India & $\begin{array}{l}\text { Antileukaemia } \\
\text { and antitumor }\end{array}$ & Amna et al. 2006 \\
\hline $\begin{array}{l}\text { Fusarium } \\
\text { oxysporum }\end{array}$ & $\begin{array}{l}\text { Dianthus caryophyllus } \\
\text { (Carnation, Divine } \\
\text { flower) }\end{array}$ & $\begin{array}{l}\text { gastrointestinal system, } \\
\text { improve heart health }\end{array}$ & $\begin{array}{l}\text { Mediterranean } \\
\text { region }\end{array}$ & Antimicrobial & $\begin{array}{l}\text { Postma and } \\
\text { Rattink } 1991\end{array}$ \\
\hline $\begin{array}{l}\text { Fusarium } \\
\text { oxysporum }\end{array}$ & $\begin{array}{l}\text { Juniperus recurva } \\
\text { (Himalayan juniper) }\end{array}$ & For long-continued vomiting & Pakistan & - & Kour et al. 2008 \\
\hline Fusarium solani & $\begin{array}{l}\text { Apodytes dimidiata } \\
\text { (White pear) }\end{array}$ & $\begin{array}{l}\text { Intestinal parasites ear } \\
\text { inflammation }\end{array}$ & Southern Africa & $\begin{array}{l}\text { Anticancer } \\
\text { (topotecan and } \\
\text { irinotecan }\end{array}$ & Shweta et al. 2010 \\
\hline Guignardia sp. & $\begin{array}{l}\text { Spondias mombin } \\
\text { (Java plum) }\end{array}$ & $\begin{array}{l}\text { Eye inflammation, diarrhea, } \\
\text { venereal diseases }\end{array}$ & America & $\begin{array}{l}\text { Antiviral, } \\
\text { Antibacterial }\end{array}$ & $\begin{array}{l}\text { Rodrigues- } \\
\text { Heerklotz } \\
\text { et al. } 2001\end{array}$ \\
\hline Muscodor albus & $\begin{array}{l}\text { Cinnamomum } \\
\text { zeylanicum } \\
\text { (Cinnamon) }\end{array}$ & Oldest herbal medicines & Sri Lankan & $\begin{array}{l}\text { Antifungal } \\
\text { Antibacterial }\end{array}$ & Strobel 2006 \\
\hline Muscodor albus & $\begin{array}{l}\text { Guazuma ulmifolia } \\
\text { (Bastard cedar) }\end{array}$ & $\begin{array}{l}\text { Weight loss, bleeding, } \\
\text { childbirth, cold, cough }\end{array}$ & America & $\begin{array}{l}\text { Antibacterial. } \\
\text { Antifungal }\end{array}$ & Strobel et al. 2007 \\
\hline Muscodor crispans & $\begin{array}{l}\text { Ananas ananassoides } \\
\text { (Wild pineapple) }\end{array}$ & Gastric pain & Bolivia, Brazil & Anti-tuberculosis & $\begin{array}{l}\text { Mitchell et al. } \\
2010\end{array}$ \\
\hline Mycorrhizal fungi & $\begin{array}{l}\text { Rhododendron } \\
\text { tomentosum (Labrador } \\
\text { tea) }\end{array}$ & $\begin{array}{l}\text { coughs, dyspepsia, dysentery, } \\
\text { leprosy, itch }\end{array}$ & North America & $\begin{array}{l}\text { antibacterial and } \\
\text { antioxidant }\end{array}$ & Kajula et al. 2010 \\
\hline Neotyphodium sp. & $\begin{array}{l}\text { Festuca arundinacea } \\
\text { (Tall fescue) }\end{array}$ & - & Europe & - & $\begin{array}{l}\text { Sugawara et al. } \\
2004\end{array}$ \\
\hline $\begin{array}{l}\text { Nigrospora sp., } \\
\text { Alternaria } \mathrm{sp} .\end{array}$ & $\begin{array}{l}\text { Aegle marmelos } \\
\text { (Bel, Siriphal) }\end{array}$ & Wound healer, scurvy. & India & Antimicrobial & Gond et al. 2007 \\
\hline Paecilomyces sp. & $\begin{array}{l}\text { Torreya grandis } \\
\text { (Chinese nutmeg yew) }\end{array}$ & Skin infections & China & $\begin{array}{l}\text { Antitumor, } \\
\text { antifungal, } \\
\text { antiinflammation }\end{array}$ & Huang et al. 2001 \\
\hline $\begin{array}{l}\text { Penicillium } \\
\text { commune }\end{array}$ & Hibiscus tiliaceus & Fevers, coughs & Southeast Asia & Antimicrobial & Yan et al. 2010 \\
\hline $\begin{array}{l}\text { Penicillium } \\
\text { chrysogenum, } \\
\text { Aspergillus } \\
\text { fumigates }\end{array}$ & $\begin{array}{l}\text { Catharanthus roseus } \\
\text { (Sadabahar) }\end{array}$ & $\begin{array}{l}\text { Blood clotting, eyewash, } \\
\text { diabetes }\end{array}$ & India & Anticancer & $\begin{array}{l}\text { Kharwar et al. } \\
2008\end{array}$ \\
\hline $\begin{array}{l}\text { Pestalotiopsis } \\
\text { microspora }\end{array}$ & Terminalia morobensis & anti-oomycetic & $\begin{array}{l}\text { Papua New } \\
\text { Guinea }\end{array}$ & $\begin{array}{l}\text { Antifungal, } \\
\text { antioxidant }\end{array}$ & Harper et al. 2003 \\
\hline $\begin{array}{l}\text { Pestalotiopsis } \\
\text { pauciseta }\end{array}$ & Tabebuia pentaphylla & $\begin{array}{l}\text { flu, cold and easing smoker's } \\
\text { cough }\end{array}$ & Mexico & $\begin{array}{l}\text { Expectorant, } \\
\text { antimicrobial }\end{array}$ & $\begin{array}{l}\text { Vennila et al. } \\
\text { (2010) }\end{array}$ \\
\hline Phoma capitulum & Justicia gendarussa & Cough, fever & China & Antispasmodic, & Gangadevi and \\
\hline
\end{tabular}




\begin{tabular}{|c|c|c|c|c|c|}
\hline & (Nilinirgundi) & $\begin{array}{l}\text { treatment of pains in the } \\
\text { head, paralysis }\end{array}$ & & carminative & Muthumary 2008 \\
\hline $\begin{array}{l}\text { Phoma eupyrena, } \\
\text { Cladosporium } \\
\text { cladosporioides }\end{array}$ & $\begin{array}{l}\text { Azadirachta indica } \\
\text { (Neem) }\end{array}$ & $\begin{array}{l}\text { Skin disease diabetic, } \\
\text { antibacterial, antiviral }\end{array}$ & India & Antimicrobial & Mahesh et al. 2005 \\
\hline Phoma medicaginis & Medicago sp. & digestive tract and kidneys & Italy & Antimicrobial & Weber et al. 2004 \\
\hline Phoma sorghina & $\begin{array}{l}\text { Tithonia diversifolia } \\
\text { (Mexican sunflower) }\end{array}$ & $\begin{array}{l}\text { Sprains, bone fractures, } \\
\text { hepatitis }\end{array}$ & West Africa & Antimicrobial & $\begin{array}{l}\text { Borges and Pupo } \\
2006\end{array}$ \\
\hline Phoma sp. & $\begin{array}{l}\text { Fagonia cretica } \\
\text { (Dhamsha) }\end{array}$ & $\begin{array}{l}\text { Fever, vomiting, dysentery, } \\
\text { typhoid, toothache, stomach } \\
\text { troubles, skin diseases }\end{array}$ & $\begin{array}{l}\text { Alicante, } \\
\text { Spain }\end{array}$ & Antifungal, algicidal & Krohn et al. 2007 \\
\hline Phoma sp. & $\begin{array}{l}\text { Saurauia scaberrinae } \\
\text { (Guinea plant) }\end{array}$ & $\begin{array}{l}\text { Fever and in holistic health } \\
\text { care }\end{array}$ & Australia & Antibacterial & $\begin{array}{l}\text { Hoffman et al. } \\
2008\end{array}$ \\
\hline Phomapsis & Coffea arabica & $\begin{array}{l}\text { Stimulant and hypnotic. } \\
\text { Analgesic, cardiotonic }\end{array}$ & India & Antimicrobial & Sette et al. 2006) \\
\hline $\begin{array}{l}\text { Phyllosticta sp., } \\
\text { Colletotrichum sp. }\end{array}$ & $\begin{array}{l}\text { Pasania edulis } \\
\text { (Japanese oak) }\end{array}$ & Skin disease & Japan & Antimicrobial & Hata et al. 2002 \\
\hline Phyllosticta sp. & $\begin{array}{l}\text { Guazuma tomentosa } \\
\text { (Mutamba) }\end{array}$ & $\begin{array}{l}\text { Childbirth, wound healing, } \\
\text { diarrhea and dysentery } \\
\text { asthma }\end{array}$ & $\begin{array}{l}\text { Tropical } \\
\text { America }\end{array}$ & Antimicrobial & $\begin{array}{l}\text { Srinivasan et al. } \\
2010\end{array}$ \\
\hline $\begin{array}{l}\text { Pichia } \\
\text { guilliermondii }\end{array}$ & $\begin{array}{l}\text { Paris polyphylla } \\
\text { (Satuwa) }\end{array}$ & $\begin{array}{l}\text { Poisonous snake bites, boils } \\
\text { and ulcers fever, headache }\end{array}$ & China & $\begin{array}{l}\text { Antibacterial } \\
\text { activity }\end{array}$ & Zhao et al. 2010 \\
\hline $\begin{array}{l}\text { Seimatoantlerium } \\
\text { nepalense }\end{array}$ & $\begin{array}{c}\text { Taxus wallichiana } \\
\text { (Himalayan yew) }\end{array}$ & Cardiac remedy & Europe & Anticancer & $\begin{array}{l}\text { Bashyal } \\
\text { et al.1999 }\end{array}$ \\
\hline $\begin{array}{l}\text { Taxomyces } \\
\text { andreanae }\end{array}$ & $\begin{array}{l}\text { Taxus sp. } \\
\text { (Yew plant) }\end{array}$ & Cancer & North America & Anticancer & Stierle et al.1993 \\
\hline $\begin{array}{l}\text { Taxomyces } \\
\text { andreanae }\end{array}$ & $\begin{array}{l}\text { Taxus brevifolia } \\
\text { (Pacific yew) }\end{array}$ & Cancer & North America & $\begin{array}{l}\text { Anticancer, lung } \\
\text { cancer }\end{array}$ & $\begin{array}{l}\text { Wiyakrutta et al. } \\
2004\end{array}$ \\
\hline
\end{tabular}

Oxytropis lambertii and Oxytropis sericea. It is native of northern China and Mongolia. Astragalus mollissimus has been used for anaemia and blood disorders, blenorrhea (profuse mucous discharge from the vagina or urethra), as an ointment for burns and to stimulate the immune system and suppress tumors. Moreover, it is used to treat chronic weakness of the lungs with shortness of breath, collapse of energy, prolapse of internal organs, spontaneous sweating, chronic lesions, and deficiency edema. These produce the alkaloid swainsonine that causes locoism, a disease of ruminant animals (Braun et al. 2003). Thus, some endophytic fungi produce novel secondary metabolites of industrial potential (Schulz et al. 2002; Worapong et al. 2002) while others enhance the fitness of their host plants (Redman et al. 2002). The mycoendophyte Taxomyces andreanae, which produces taxol in vitro, was isolated from Taxus sp. (Stierle et al. 1993). Vennila et al. (2010) studied the effect of taxol extracted from the endophytic fungus Pestalotiopsis pauciseta recovered from Tabebuia pentaphylla Hems. T. pentaphylla (family Bignoniaceae) is distributed in northern Mexico, Southern Florida and Cuba. The generic name is derived from the words used for the trees by the indigenous peoples of Brazil. It is used against flu, cold and easing smoker's cough. Apparently, it acts as expectorant, by promoting the lungs to cough up and free deeply embedded mucus and contaminants.

Zhou et al. (2010) summarized the recent advances in taxol-producing endophytic fungi all over the world. Kajula et al. (2010) studied the extracellular siderophore production as well as production of antibacterial and antioxidant compounds by endophytic fungi of Scots pine (Pinus sylvestris L.) and Labrador tea (Rhododendron tomentosum Harmaja). The pinolenic acid contained in pine nut oil helps curb appetite. It is used as a pain reliever in arthritis, aches, pains and sore muscles. It is an important remedy for bladder, kidney, and rheumatic affections, diseases of the mucous membrane and respiratory complaints; externally in the form of liniment plasters and inhalants. Labrador tea is useful in coughs, dyspepsia, and irritation of the membranes of the chest. An infusion of the tea has been used to soothe irritation in infectious, feverish eruptions, in dysentery, leprosy, and itch, etc.

Yang et al. (1994) reported that the phenol and phenolic acids, detected in culture medium of endophytes, often have pronounced biological activities. 2-Hydroxy-6-methyl benzoic acid was isolated from endophytic Phoma species which showed remarkable antibacterial activity. Phoma medicaginis exists as a prolonged asymptomatic infection of its host plant (Medicago species). In early Chinese medicines, physicians used young leaves of Medicago species to treat disorders related to the digestive tract and the kidneys. It produces significant levels of the toxin Brefeldin, during and after switching from the endophytic to the saprotrophic phase when the host dies (Weber et al. 2004). Suryanarayanan et al. (2005) studied the cactus Cylindropuntia fulgida for its endophytic diversity. The stem of certain Cacti has been investigated for the treatment of type II diabetes, reductions in nausea, dry mouth, and loss of appetite as well as less risk of a severe hangover.

Karsten et al. (2007) reported herbicidal and algaecidal activity in ethyl acetate extract of an endophytic Phoma sp. isolated from Fagonia cretica, F. cretica is used against fever, thirst, vomiting, dysentery, asthma, urinary 
discharges, liver trouble, dropsy, delirium, typhoid, toothache, stomach troubles, and skin diseases. Randa et al. (2010) isolated a mycoendophyte (Botryosphaeria rhodina) from the stem of the medicinal plant Bidens pilosa (Asteraceae) that showed anti-inflammatory, antiseptic and antifungal effects. Bidens pilosa is used as a medicinal plant in many regions of Africa, Asia and tropical America. The extract of Botryosphaeria rhodina also had significant cytotoxic and antiproliferative effects against several cancer cell lines.

Borges and Pupo (2006), has reported two novel hexahydroanthraquinone derivatives, dendryol $\mathrm{E}$ and $\mathrm{F}$ isolated from Phoma sorghina, which was found as an endophyte associated with a medicinal plant Tithonia diversifolia. The dried leaves of $T$. diversifolia showed anti-inflammatory and analgesic activities. Schwarz et al. (2004) optimized the culture conditions of Phoma species and reported highest nematicidal activity in yeast malt glucose medium. Also, the secondary metabolites produced on Czapeck yeast autolysate and Yeast extract sucrose media by several Phoma species, separated by thin layer chromatography clarified the systematics of the genus (Montel et al. 1991). Phomodione, 2,6-diacetyl-7-hydroxy4a,9-dimethoxy-8,9b-dimethyl-4a.9b-dihydrodibenzo furan1,3, an usnic acid derivative, were isolated from culture broth of a Phoma species which was an endophyte in the Guinea plant (Saurauia scaberrinae). Usnic acid and two of its derivatives, cercosporamide, and phomodione, were also isolated from this fungus (Hoffman et al. 1998) Smith et al. (2008) provided direct evidence from bioassays of endophytes isolated from tropical plants and bioinformatic analyses, that gives novel chemistry of potential value.

Raviraja (2005) studied eighteen species of mycoendophytes, isolated from bark, stem and leaf segments of five medicinal plant species growing within the Kudremukh range in the Western Ghats of India. The most common endophytic fungi were Curvularia clavata, C. lunata, C. pallescens and Fusarium oxysporum. The greatest species richness and frequency was found in the leaf segments, rather than the stem and bark segments of the host plant species. Thus, if endophytes could produce the same rare and important bioactive compounds as their host plants, this would not only reduce the need to harvest slow-growing and possibly rare plants but also help to preserve the world's ever-diminishing biodiversity.

\section{PIRIFORMOSPORA INDICA: A NOVEL GROWTH PROMOTING ENDOPHYTE}

In 1998, Varma and colleagues discovered Piriformospora indica in the desert soil of Rajasthan and proved that it belongs to Basidiomycotina. The formation of pyriform chlamydospores is an important feature of this fungus. $P$. indica has tremendous capacity to enhance growth of host plant through its root-colonization (Rai et al. 2001). It is similar to arbuscular mycorrhizal fungi in many respects (Rai and Varma 2005; Deshmukh et al. 2006). Inoculation with fungus or with culture filtrates can enhance host plant biomass. $P$. indica acts as multifunctional fungus because of its role as a biofertilizer, bioprotector, growth regulator, or it can increase drought tolerance (Sun et al. 2010). Recently, Yadav et al. (2010) reported that a phosphate transporter gene (PiPT) plays an important role during the transport of phosphate from this fungus to the host plant. Hence, the endophyte, $P$. indica has provided new insight for understanding the mechanism of phosphate transfer in host plants. There are many advantages of using $P$. indica in agriculture and forestry (Singh et al. 2003; Yadav et al. 2010). P. indica can be used as a biological control agent against soil-borne root pathogens. The severity of the disease caused by Pseudocercosporella herpotrichoides and Fusarium culmorum were reduced when roots of winter wheat were colonized with $P$. indica. Kumar et al. (2009) also studied bioprotection potential of $P$. indica against Fusarium verticillioides, a root parasite and showed improvement in biomass, root length and number as compared with controls. Antioxidant enzyme activities were reduced by the presence of $P$. indica which helped the host plant.

Piriformospora indica has also proved to be a valuable tool for biological hardening of micropropagated plantlets. Regenerated plantlets of tobacco subjected to two different biological hardening techniques showed $88-94 \%$ survival when inoculated as a root endophyte with $P$. indica, but only $62 \%$ survival in uninoculated controls. Thus, $P$. indica enhances plant growth, and survival via a positive impact on the nutritional and water status of the plant. It increases the reproductive potential, improves root performance, and provides natural defense against invaders, including pests and pathogens (Prasad et al. 2008).

\section{ENDOPHYTES: THE NEW AND ECO-FRIENDLY DRUG PRODUCERS}

The number of eco-friendly drugs produced by mycoendophytes is large as compared to endophytic bacteria. Natural products from fungal endophytes can be grouped into several categories, including alkaloids, steroids, terpenoids, isocoumarins, quinones, phenylpropanoids and lignans, phenol and phenolic acids, aliphatic metabolites, lactones, etc.

A novel amide, characterized as a rasfarnesyltransferase inhibitor was extracted from the culture broth of an endophytic Phoma species (Ishii et al. 2000). Mycoendophytes are being increasingly accepted as an ecological group of micro-organisms that may provide sources for new secondary metabolites with useful biological activities. An array of active principle has been isolated and characterized from endophytes and many of these have diverse bioactivities (anti-cancerous, antioxidants, anti-fungal, antibacterial, anti-viral, antiinsecticidal and immune suppressants). Yang et al. (2006) reported two new 12-membered ring lactones isolated from the mycelial extracts of Cladosporium tenuissimum. Additional polyketides 12-membered macrolides have been produced by the endophytic $C$. tenuissimum of Maytenus hookeri (Silky bark). Mycoendophyte Nodulisporium species associated with Juniperus cedre (Juniper), 
produced seven new metabolites. Chaetominine, an alkaloid with a new framework, produced by endophytic Chaetomium species was isolated from Adenophora axiliflora. The cytotoxic effect shown by the Chaetominine, against the human leukemia K562 and colon cancer SW1116 cell lines was higher than the drug 5fluorouracil (Jiao et al. 2006). Phaeosphoramides and two new carbon skeleton derivatives were isolated from the endophytic Phaeosphaeria avenaria. Phaeosphoramide was found to be an inhibitor of the signal transducer and activator of transcription. This plays a vital role in regulating cell growth and survival, constituting a target for anticancer therapy (Maloney et al. 2006). Sumarah et al. (2010) identified the fungal endophytes from Picea rubens (red spruce) needles, isolated the active principles, and evaluated their toxicity. $P$. rubens is a species of spruce native to eastern North America. Three strains were toxic to the forest pest Choristoneura fumiferana (eastern spruce budworm). Leafy red spruce twigs are boiled for making spruce beer.

\section{ANTICANCER AND ANTI-TUBERCULOSIS COMPOUNDS}

Cancer is a group of diseases characterized by unregulated growth and spread of abnormal cells, which can result in death if not controlled (Pimentel et al. 2010). It has been considered as one of the major causes of death worldwide (about $13 \%$ of all deaths). Evidence is present about bioactive compounds produced by endophytes and could be an alternative approach for discovery of novel drugs, since many natural products from plants, microorganisms, and marine sources were identified as anticancer agents (Firakova et al. 2007). The anticancer properties of several secondary metabolites from endophytes have been investigated recently. The first anticancer agent produced by endophytes was Taxol and its derivatives. Taxol is a highly functionalized diterpenoid, isolated from yew (Taxus) species (Bacon and White 1994). The mode of action of Taxol is to prevent tubulin molecules from depolymerization during the processes of cell division (Tan and Zou 2001). Camptothecin another potent antineoplastic agent, was firstly isolated from the wood of Camptotheca acuminata Decaisne (Nyssaceae) in China (Wall et al. 1966). Camptothecin and 10hydroxycamptothecin are two important precursors for the synthesis of the clinically useful anticancer drugs, topotecan, and irinotecan (Uma et al. 2008). The products were obtained from the endophytic fungi Fusarium solani isolated from Camptotheca acuminate (Kusari et al. 2009). Ergoflavin, is an another dimeric xanthene linked in position 2 compound, belongs to the class ergochromes and is described as a novel anticancer agent isolated from endophytic fungi growing on the leaves of an Indian medicinal plant Mimusops elengi (Sapotaceae) (Deshmukh et al. 2009). Another compound Secalonic acid D, a mycotoxin belonging to ergochrome class, is known to have potent anticancer activities, was isolated from the mangrove endophytic fungus demonstrated high cytotoxicity on HL60 and K562 cells by inducing leukemia cell apoptosis (Zhang et al. 2009). More novel 22-oxacytochalasins (Figure 1.A) (anti-cancer) drugs are also required worldwide to combat this scourge. These compounds have antitumor activity (Bills et al. 1996). Crude Extracts of endophytic fungus Alternaria alternata, isolated from Coffea Arabica L., showed moderate cytotoxic activity to HeLa cells in vitro, when compared to the dimethyl sulfoxide (DMSO) treated cells (Fernandes et al. 2009). Tripterygium wilfordii is used in traditional Chinese medicine for the treatment of fever, chills, edema, and carbuncle. There is a need to search for new antimicrobial agents because infectious diseases are still a global problem due to the development and spread of drugresistant pathogens.

Rukachaisirikul et al. (2007) reported endophytic Phomopsis species which produces secondary metabolites like phomoenamide, phomonitroester, and Deacetylphomoxanthone, and showed antibacterial activity against Mycobacterium tuberculosis. Gordien et al. (2010) studied extracts from Scottish plants, lichens, and mycoendophyte which were screened for activity against Mycobacterium aurum and $M$. tuberculosis. The greatest activity against $M$. aurum was shown by extracts of Juniperus communis roots, of the lichen Cladonia arbuscula and of a mycoendophyte isolated from Vaccinium myrtillus (Gordien et al. 2010). It is obvious that mycoendophytes serve as a source of potentially useful medicinal compounds. For example, 3-nitropropionic acid was isolated from Phomopsis species which inhibited Mycobacterium tuberculosis and harbors anti-tuberculosis activity (Copp and Pearce 2007).

Alkaloids: These are useful anticancer agents that are often found in endophytic fungi. Wagenaar et al. (2000) isolated three novel cytochalasins from endophytic Rhinocladiella species which demonstrated antitumor activity. Most of the alkaloids have been detected in the cultures of grass-associated mycoendophyte, such as sexual Epichloe spp. and asexual Neotyphodium species. Although metabolite production can be influenced by environmental factors, it seems to depend mostly on the strain or genotype of the endophytic species and less on the host grass genotype (Siegel et al. 1990). The alkaloids from mycoendophyte include amines and amides, indole derivatives, pyrrolizidines and quinazolines (Figure $1 \mathrm{~B}$ ). Amines and amides are common substances produced by mycoendophyte from tall fescue, perennial ryegrass and many temperate grasses (Wilkinson et al. 2000). The ergot alkaloids are the second group of amine and amide alkaloids discovered in cultures of Neotyphodium endophytes, all are being characterized previously from ergot sclerotia (Tan and Zou 2001). These metabolites were later demonstrated to be neurotoxic to insects and mammal herbivores. Ergovaline and other structurally related ergopeptides are likely responsible for the toxicosis of livestock that consumes endophyte-infected tall fescue. The biosynthesis of ergot alkaloids such as ergovaline is better understood in the ergot fungus Claviceps purpurea.

Steroids and terpenoids: Steroids have many important physiological effects, and some are found in 
mycoendophyte. A novel ergosterol derivative, 4a-homo22-hydroxy-4-oxaergasta-7, was isolated from a strain of Gliocladium sp., an endophyte on Taxus chinensis (Chinese yew). In addition to four cytochalasins, eleven novel sesquiterpenoids were isolated from cultures of the mitosporic fungus Geniculosporium species an endophyte associated with the red alga Polysiphonia species (Krohn et al. 2005).

Quinones, phenylpropanoids, and lignans: Highly functionalized cyclohexenone epoxides, jesterone, and hydroxyjesterone, were characterized from a newly identified endophyte Pestalotiopsis jesteri present in Fragraea bodenii. Guignardic acid is the first member of a novel class of natural products which were detected in the culture broth of Guignardia species obtained from Spondias mombin (Golden apple) (Rodrigues et al. 2001), which is a member of family Anacardiaceae native to tropical America, including the West Indies. In the past, it had been used as a febrifuge, diuretic, for leprosy, severe cough causing relief through vomiting.

Phenols, phenolic acids, and antioxidants: Phenols and phenolic acids from fungal endophytes usually have pronounced biological and antioxidant activities. Pestacin and isopestacin are two novel dihydro isobenzofurancarrying phenols possessing antifungal and antioxidant activities (Figure $1 \mathrm{C}$ and D). These were extracted from endophytic Pestalotiopsis microspora isolated from Terminalia morobensis (Harper et al. 2003). Both pestacin and isopestacin showed antimicrobial and antioxidant activity confirmed by electron spin resonance spectroscopy measurements. They are able to scavenge superoxide and hydroxyl free radicals in solution (Lewis et al. 1997).

Aliphatic compounds and lactones: Chaetomellic acid, a potent and highly specific inhibitor of farnesylprotein transferase was characterized from the endophyte Chaetomella acutisea. Seven lactones were also characterized by an unidentified ascomycete endophyte isolated from Cistus salviifolius (White Rockrose) in Chile (Kopcke et al. 2002).

\section{ANTIOXIDANT COMPOUNDS}

Antioxidant activity of a compound is actually the effectiveness of the compound against damage caused by reactive oxygen species (ROSs) and oxygen-derived free radicals, which contribute to a variety of physiological and pathological effects, for instance, DNA damages, carcinogenesis, and cellular degeneration (Haung et al. 2007; Seifried et al. 2007). Antioxidants are considered promising therapy for prevention and treatment of ROSlinked diseases as cancer, cardiovascular disease, atherosclerosis, hypertension, ischemia/reperfusion injury, diabetes mellitus, neurodegenerative diseases like Alzheimer and Parkinson diseases, rheumatoid arthritis, and aging (Valko et al. 2007).

Naturally occurring antioxidant compounds are commonly found in vegetables, fruits, and medicinal plants. However, it has been observed that endophytes are also a potential source of novel natural antioxidants. Endophytic Xylaria sp. isolated from the medicinal plant
Ginkgo biloba, contain compounds showing antioxidant activities (Liu et al. 2007). Pestacin and isopestacin (1,3dihydro isobenzofurans), were obtained from the endophytic fungus Pestalotiopsis microspora isolated from Terminalia morobensis a plant growing in the Papua New Guinea (Strobel et al. 2002; Harper et al. 2003). These compounds mainly isopestacin possess antioxidant activity by scavenging both superoxide and hydroxy free radicals in solution, added to the fact that isopestacin is structurally similar to the flavonoids (Strobel et al. 2002). Graphislactone A, a phenolic compound isolated from the endophytic fungus Cephalosporium sp. residing in Trachelospermum jasminoides, demonstrated to have free radical-scavenging and antioxidant activities in vitro stronger than the standards, butylated hydroxytoluene (BHT) and ascorbic acid, assayed in the study (Song et al. 2005).

\section{ANTIBIOTICS, ANTIFUNGAL, AND ANTIVIRAL COMPOUNDS}

Antibiotics are defined as low-molecular-weight organic natural products made by microorganisms that are active at low concentration against other microorganisms (Moon et al. 2002). Antibiotics from endophytic microbes have been reported to inhibit a variety of pathogens. For example, Cryptocandin is a unique antimycotic peptide isolated from Cryptosporiopsis quercina (Mohali et al. 2005) (Figure 1 E, F, and G). Similarly, Pestalotiopsis microspora, isolated from Torreya taxifolia produces several antifungal compounds. These include pestaloside, an aromatic glucoside, and two pyrones: pestalopyrone and hydroxyp-estalopyrone. $T$. taxifolia, is a rare and endangered species found in the Southeastern United States. It is used for the treatment of cancer. Other novel sesquiterpenes produced by endophytic fungi are 2hydroxydimeninol and a highly functionalized humulane (Surette et al. 2003).

Endophytic Muscodor albus was isolated from small limbs of Cinnamomum zeylanicum (Strobel 2006). This xylariaceaous (non-spore producing) fungus inhibits and kills certain other fungi and bacteria by producing a mixture of volatile compounds. Two novel human cytomegalovirus protease inhibitors, cytonic acids, have been isolated from the endophytic Cytonaema sp. (Schmid et al. 1993). Guo et al. (2008) studied the new antimicrobial metabolites isolated and extracted from the culture of Colletotrichum species from Artemisia апnиa, which is a traditional Chinese herb. It is well recognized for its synthesis of artemisinin (an antimalarial drug). These metabolites demonstrated activity against fungi and bacteria.

Endophytic fungi of the genera Xylaria, Phoma, Hypoxylon, and Chalara are producers of a group of substances known as the cytochalasins, of which over 20 are known. Many of these compounds possess antibiotic activities, but because of their cellular toxicity, they have not been developed into pharmaceutical drugs. Three novel cytochalasins have recently been reported from a Rhinocladiella sp. as an endophyte on Tripterygium wilfordii. 
<smiles>CC1CCC(=O)OC23C(=O)NC(Cc4ccccc4)C2C(C)C2(C)OC2C3/C=C/CC(C)(O)C(=O)C1C</smiles>

A<smiles>Cc1cc(O)c2c(c1)C(c1c(O)cccc1O)OC2=O</smiles>

C<smiles>Cc1cc(O)c2c(c1)CCO[C@H]2c1c(O)cccc1O</smiles>

D

<smiles>CC(=O)C1=CCN2C(=O)C(c3ccccc3)=C(c3ccccc3)C12C</smiles><smiles>CC(=O)C1C(O)CN2C(=O)C(c3ccccc3)=C(c3ccccc3)C12C</smiles>

B

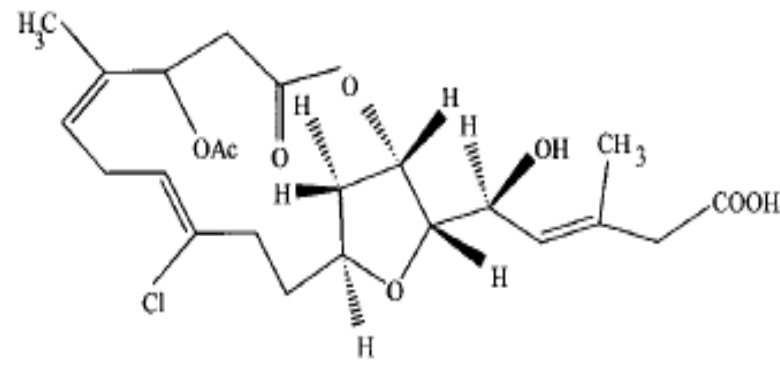

$\mathbf{E}$

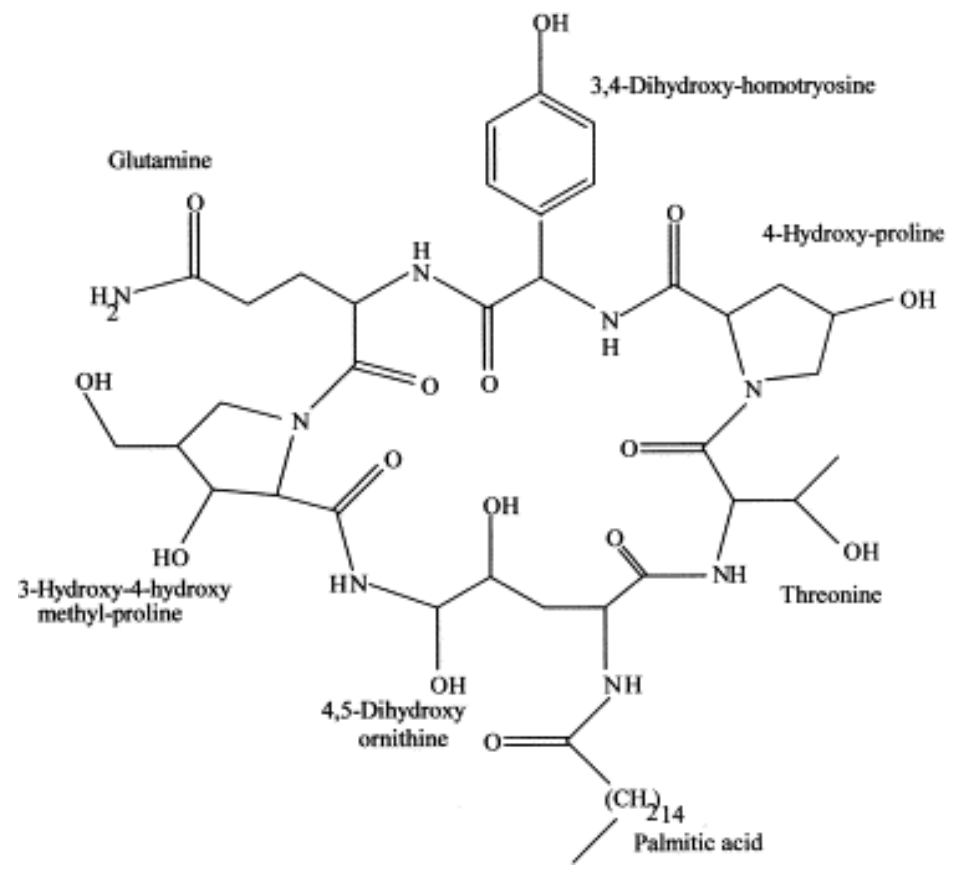

G

Figure 1. Structure of compounds produced by endophytes (A) Cytochalasins antitumor compound from an endophyte Rhinocladiella sp., (B) Pyrrolizidines, (C) Isopestacin (D) Pestacin an antioxidant produced by an endophytic Pestalotiopsis microspora strain recovered from Terminalia morobensis (E) Oocydin (F) Periconicin, (G) Cryptocandin 


\section{FUTURE PERSPECTIVES AND CONCLUSIONS}

The need for new bioactive to overcome the growing problems of drug resistance in microorganisms and the appearance of new diseases is of increasing importance. The capability of fungi to produce bioactive metabolites has encouraged researchers to isolate and screen fungi from diverse habitat and environments to search for novel bioactive metabolites.

Some endophytes produce phytochemical that were originally thought of as characteristic of the host plant. It appears that genetic interaction between the endophyte and the host has occurred over evolutionary time (Tan and Zou 2001). This concept was proposed to explain why Taxomyces andreanae produce taxol. The cultured endophytes, can be induced to produce the same rare and important bioactive compounds as when associated with their host plants, it would reduce the need to harvest slowgrowing and possibly rare plants. It would also help to preserve the world's ever-diminishing biodiversity. Furthermore, a microbial source of a high-value product is an economical way to produce a metabolite in a bulk quantity and thereby reduce its market price.

Researchers are searching for new antibiotics, chemotherapeutic agents, and agrochemicals that are highly effective, possess low toxicity, and have a minor environmental impact. This search is driven by the development of resistant infectious microorganisms e.g., species of Mycobacterium, Streptococcus, and Staphylococcus. Furthermore, new diseases, like AIDS and respiratory syndrome, need the invention and development of novel active drugs to fight them. Diseases such as AIDS require drugs that target them specifically and also new therapies for treating the ancillary infections which are the consequence of a weakened immune system. New drugs are needed for immunocompromised cancer patients and those receiving organ transplants and those who are at risk of opportunistic pathogens, such as Aspergillus spp., Cryptococcus spp. and Candida spp. Finally, a number of synthetic agricultural products have been removed from the market due to safety and environmental problems so there is also a need to discover an alternative to control crop pests and pathogens.

To overcome the infectious disease, there is a need for a variety of novel antimicrobial compounds of biological origin. The mycoendophytes hold enormous potential as sources of antimicrobials. These endophytes may open new vistas for the development of new drugs and agricultural products. The multi-drug resistance problem in microbes underscores the need for further research on novel metabolites obtained from mycoendophytes.

\section{ACKNOWLEDGEMENTS}

We are thankful to the Ministry of Environment and Forest, Government of India, New Delhi for providing financial assistance for research on endophytes.

\section{REFERENCES}

Amna T, Khajuria RK, Puri SC, Verma V, Qazi GN. 2006. Determination and quantification of camptothecin in an endophytic fungus by liquid chromatography positive mode electrospray ionization tandem mass spectrometry. Curr Sci 91 (2): 208-212

Arnold AE, Maynard Z, Gilbert GS, Coley PD, Kursar TA. 2003. Are Tropical Fungal Endophytes Hyperdiverse? Ecol Lett 3: 267-274.

Bacon CW, Porter JK, Robins JD, Luttrell ES. 1977. Epichloë typhi from toxic tall fescue grasses. Appl Environ Microbiol 34: 576-581.

Bacon CW, White JF. 1994. Biotechnology of Endophytic Fungi of Grasses. CRC Press, Boca Raton, FL, USA.

Bashyal B, Li JY, Strobel GA, Hess WM. 1999. Seimatoantlerium nepalense, an endophytic taxol producing coelomycete from Himalayan yew (Taxus wallichiana). Mycotaxon 72: 33 .

Bills GF. 1996. Isolation and analysis of endophytic fungal communities from woody plants in Endophytic Fungi in Grasses and Woody Plants. Ecology and Evolution, USA, pp. 31-65.

Borges WS, Pupo MT. 2006. Novel anthraquinone derivatives produced by Phoma sorghina, an endophyte found in association with the medicinal Plant Tithonia diversifolia (Asteraceae). J Braz Chem Soc 17: 929-934.

Braun K, Romero J, Lidell C, Creamer R. 2003. Production of swainsonine by fungal endophytes of locoweed. Mycological Research 107: 980-988.

Copp BR, Pearce AN. 2007. Natural product growth inhibitors of Mycobacterium tuberculosis. R Soc Chem 24: 278-297

Deshmukh S, Hückelhoven R, Schäfer P. 2006). The root endophytic fungus Piriformospora indica requires host cell death for proliferation during mutualistic symbiosis with barley. Proc Nat Acad Sci 49: 18450-18457.

Deshmukh SK, Mishra PD, Kulkarni A, et al.. 2009. Anti-inflammatory and anticancer activity of ergoflavin isolated from an endophytic fungus. Chem Biodiv 6: 784-789.

Deshmukh SK, Verekar SA. 2008. Fungal Endophytes: A potential source of anticancer compounds. In: Carpinella C, Rai M (eds), Novel therapeutic agents from natural origin: Progress and future perspectives. Science Publisher, USA .

Dreyfuss MM, Chapela IH. 1994. Potential of fungi in the discovery of novel, low-molecular-weight pharmaceuticals. In: Gullo VP. (ed.) the discovery of natural products with therapeutic potential. ButterworthHeinemann, Boston, USA.

Fernandes MDRV, Silva TAC, Pfenning LH, et al. 2009. Biological activities of the fermentation extract of the endophytic fungus Alternaria alternata isolated from Coffea arabica L. Braz J Pharm Sci 45: 677-685.

Firakova S, Sturdikova M, Muckova M. 2007. Bioactive secondary metabolites produced by microorganisms associated with plants. Biologia 62: 251-257.

Gangadevi V, Muthumary J. 2008. A simple and rapid method for the determination of taxol produced by fungal endophytes from medicinal plants using high performance thin layer chromatography. Chin $\mathbf{J}$ Chromatogr 26 (1): 50-55.

Gehlot P, Bohra, NK, Purohit DK. 2008. Endophytic Mycoflora of Inner Bark of Prosopis cineraria - a keystone tree species of Indian desert. Am Eur J Bot 1 (1): 01-04.

Gond SK, Verma VC, Kumar A, Kumar V, Kharwar RN. 2007. Study of endophytic fungal community from different parts of Aegle marmelos Correae (Rutaceae) from Varanasi (India). World J Microb Biot 23: 1371-1375

Gordien AY, Gray AI, Ingleby K, Franzblau SG, Seidel V. 2010. Activity of Scottish plant, lichen and fungal endophyte extracts against Mycobacterium aurum and Mycobacterium tuberculosis. Phytother Res 24 (5): 692-8

Guo B, Wang Y, Sun X, Tang K. 2008. Bioactive Natural Products from Endophytes: A Review. Appl Biochem Microbiol 44 (2): 136-142.

Hamayun M, Khan SA, Khan AL, Rehman G, Sohn EY, Shah AA, Kim SK, Joo GJ, Lee IJ. 2009. Phoma herbarum as a new Gibberellinproducing and plant growth- promoting fungus. J Microbiol Biotech 19 (2): 12131

Harper JK, Arif AM, Ford EJ, Srobel GA, Porco JA, Tomer DP, Oneil KL, Heider EM, Grant DM. 2003. Pestacin: a 1,3-dihydro 
isobenzofuran from Pestalotiopsis microspora possessing antioxidant and antimycotic activities. Tetrahedron 59: 2471-2476.

Hata K, Atari R, Sone K. 2002. Isolation of endophytic fungi from leaves of Pasania edulis and their within-leaf distributions. Mycoscience 43 369-373.

Hawksworth DFL, Kirk PM, Sutton BC, Pegler DN. 1995. Dictionary of the Fungi, CAB Intl., New York.

Hazalin NAMN, Ramasamy K, Lim SM, Wahab IA, Cole ALJ, Abdul Majeed AB. 2009. Cytotoxic and antibacterial activities of endophytic fungi isolated from plants at the National Park, Pahang, Malaysia. Complem Alt Med 9: 46.

Herre EA, Mejia IC, Kyllo DA, Rojas E, Maynard Z, Butler L, Van bael SA. 2007. Ecological implications of anti-pathogen effects of tropical fungal endophytes and mycorrhizae. Ecology 88 (3): 550-558.

Hoffman AM, Mayer SG, Strobel GA, Hess WM, Sovocool GW, Grange AH, Harper JK, Arif AM, Grant DM, Kelley-Swift EG. 2008. Purification, identification, and activity of phomodione, a furandione from an endophytic Phoma species. Phytochemistry 69: 1049-1056

Hoffman AW, Khan J, Worapong G, Strobel D, Arbogast D, Borofsky RB, Boone L, Ning P, Zheng, D. 1998. Bioprospecting for taxol in angiosperm plant extracts. Spectroscopy 13: 22-32.

Huang WH, Cai YZ, Xing J, Corke H, Sun M. 2007. A potential antioxidant resource: endophytic fungi from medicinal plants. Ecol Bot 61: 14-30.

Huang Y, Wang J, Li G, Zheng Z, Su W. 2001. Antitumor and antifungal activities in endophytic fungi isolated from pharmaceutical plants Taxus mairei, Cephalataxus fortunei, and Torreya grandis. FEMS Immunol Med Microbiol 31: 163-167.

Ishii T, Hayashi K, Hida T, Yamamoto Y, Nozaki Y. 2000. TAN-1813, a novel Ras-farnesyltransferase inhibitor produced by Phoma sp. taxonomy, fermentation, isolation and biological activities in vitro and in vivo. J Antibiot 53 (8): 765-778.

Jiao RH, Xu S, Liu JY, Ge HM, Ding H, Xu C, Zhu HL, Tan, RX. 2006. Chaetominine, a cytotoxic alkaloid produced by endophytic Chaetomium sp. IFB-E015. Org Lett 8: 5709-5712.

Kajula M, Tejesvi MV, Kolehmainen S, Mäkinen A, Hokkanen V, Mattila S, Pirttilä AM. 2010. The siderophore ferricrocin produced by specific foliar endophytic fungi in vitro. Fun Bio 114 (2-3): 248-254.

Karsten K, Umar F, Ulrich F, Barbara S, Siegfried D, Gennaro P, Piero S, Sándor A, Tibor K. 2007. Secondary Metabolites Isolated from an Endophytic Phoma sp. Absolute Configuration of Tetrahydropyrenophorol Using the Solid-State TDDFT CD Methodology. Eur J Org Chem. 3206-3211

Khan R, Shahzad S, Choudhary MI, Khan SA, Ahmad A. 2007. Biodiversity of the Endophytic fungi isolated from Calotropis procera (AIT.) R. BR. Pakistan J Bot 39 (6): 2233-2239.

Kharwar RN, Verma1 VC, Strobel G, Ezra D. 2008. The endophytic fungal complex of Catharanthus roseus (L.) G. Don. Curr Sci 95 (2): 228-233

Kopcke B, Weber RWS, Anke H. 2002. Biology and chemistry of endophytes. Phytochemistry 60: 709

Kour A, Shawl AS, Rehman S, Sultan P, Qazi PH, Suden P, Khajuria RK, Verma V. 2008. Isolation and identification of an endophytic strain of Fusarium oxysporum producing podophyllotoxin from Juniperus recurva. World J Microb Biot 24 (7): 1115-1121.

Krohn K, Farooq U, Flörke U, Schulz B, Draeger S, Pescitelli G, Salvadori P, Antus S, Kurtán T. 2007. Secondary Metabolites Isolated from an Endophytic Phoma sp.-Absolute Configuration of Tetrahydropyrenophorol Using the Solid-State TDDFT CD Methodology. Eur J Org Chem. 3206-3211.

Krohn KJ, Dai U, Florke HJ, Aust S, Schulz B. 2005. Biology and chemistry of endophytes. J Natl Prod 68: 400.

Kumar M, Yadav V, Tuteja N, Johri AK. 2009. Antioxidant enzyme activities in maize plants colonized with Piriformospora indica. Microbiology 155: 780-790.

Kusari S, Zuhlke S, Spiteller M. 2009. An endophytic fungus from Camptotheca acuminata that produces camptothecin and analogues. J Nat Prod 72: 2-7.

Lewis GC, Ravel C, Naffaa W, Astier C, Charmet G. 1997. Biology and chemistry of endophytes. Ann Appl Biol 130: 227.

Li JG, Shun XG. 2009. Endophytic fungi from Dracaena cambodiana and Aquilaria sinensis and their antimicrobial activity. Afr J Biotechnol 8 (5): 731-736

Liu CH, Zou WX, Lu H, Tan RX. 2001. Antifungal activity of Artemisia аппиа endophyte cultures against phytopathogenic fungi. J Biotech 88: $277-282$.
Liu JY, Huang LL, Ye YH, Zou WX, Guo ZJ, Tan RX. 2006. Antifungal and new metabolites of Myrothecium sp. Z16, a fungus associated with white croaker Argyrosomus argentatus. J Appl Microbiol 100: 195-202.

Liu X, Dong M, Chen X, Jiang M, Lv X, Yan G. 2007. Antioxidant activity and phenolics of an endophytic Xylaria sp. from Ginkgo biloba. Food Chem 105: 548-554.

Mahesh B, Tejesvi MV, Nalini MS, Prakash HS, Kini KR, Ven S, Shetty HS. 2005. Endophytic mycoflora of inner bark of Azadirachta indica A. Juss. Curr Sci 88 (2): 218-219.

Maloney KN, Hao W, Xu J, Gibbons J, Hucul J, Roll D, Brady SF, Schroeder FC, Clardy J. 2006. Phaeosphaeride A, an inhibitor of STAT3-dependent signaling isolated from an endophytic fungus. Org Lett 8: 4067-4070.

Mohali S, Burgess TI, Wingfield MJ. 2005. Diversity and host association of the tropical tree endophyte Lasiodiplodia theobromae revealed using simple sequence repeat markers. Forest Pathol 35 (6): 385-396

Montel E, Bridge PD, Sutton BC. 1991. An integrated approach to Phoma systematics. Mycopathology 115: 89-103.

Moon CD, Miles CO, Jarlfors U, Schardl CL. 2002. Biology and chemistry of endophytes. Mycologia 94: 694.

Musetti R, Vecchione A, Stringher L, Borselli S, Zulini L, Marzani C, Ambrosio MD, Sanità di Toppi L, Pertot I. 2006. Inhibition of Sporulation and Ultrastructural Alterations of Grapevine Downy Mildew by the Endophytic Fungus Alternaria alternate. Phytopathology 96 (7): 689-698

Pelaez F, Collado J, Arenal F, et al. 1998. Endophytic fungi from plants living on gypsum soils as a source of secondary metabolites with antimicrobial activity. Mycol Res 102: 755-761.

Petrini OTN, Sieber LT, Viret O. 1992. Ecology metabolite production and substrate utilization in endophytic fungi. Nat Toxin 1: 185-96.

Photita W, Taylor PWJ, Ford R, Hyde KD, Lumyong S. 2005. Morphological and molecular characterization of Colletotrichum species from herbaceous plants in Thailand. Fun Diver 18: 117-133.

Pimentel MR, Molina G, Dion'isio AP, Junior RM, Pastore GM. 2011. The Use of Endophytes to Obtain Bioactive Compounds and Their Application in Biotransformation Process. Biotech Res Int. DOI: $10.4061 / 2011 / 576286$ (In press)

Postma J, Rattink H. 1991. Biological control of Fusarium wilt of carnation with a non-pathogenic of Fusarium oxysporum. Can J Bot 70: 1199-1205.

Prasad R, Sharma V, Chatterjee S, Chauhan G, Tripathi S, Das A, Kamal S, Rawat AKS, Bhutani KK, Rai MK, Pushpangdan P, Varma A. 2008. Interactions of Piriformospora indica with Medicinal Plants. Mycorrhiza. (Ed. Varma A.). Springer, Berlin.

Rai MK, Acharya D, Singh A, Varma A. 2001. Positive growth responses of the medicinal plants Spilanthes calva and Withania sonmifera to inoculation by Piriformospora indica in a field trial. Mycorrhiza 11: 123-128.

Rai MK, Varma A. 2005. Arbuscular mycorrhiza-like biotechnological potential of Piriformospora indica, which promotes the growth of Adhatoda vasica Nees. Elect J Biotechnol 8: 1-4.

Randa A, Kirstin S, Hans-Martin D, Isabel S, Christian H. 2010. Botryorhodines A-D, antifungal and cytotoxic depsidones from Botryosphaeria rhodina, an endophyte of the medicinal plant Bidens pilosa. Photochemistry 71 (1): 110-116.

Raviraja NS. 2005. Fungal endophytes in five medicinal plant species from Kudremukh Range, Western Ghats of India. J Baz Microbiol 45 (3): 230-235.

Redman RS, Sheehan KB, Stout RG, Rodriguez RJ, Henson JM. 2002. Thermotolerance generated by plant-fungal symbiosis. Science 298 : 1581.

Rodrigues-Heerklotz KF, Drandarov K, Heerklotz J, Hesse M, Werner C. 2001. Guignardic Acid, a Novel Type of Secondary Metabolite Produced by the Endophytic Fungus Guignardia sp.: Isolation, Structure Elucidation, and Asymmetric Synthesis. Helv Chim Acta 84: 3766 .

Rodriguez RJ, White Jr JF, Arnold AE, Redman RS. 2009. Fungal endophytes: diversity and functional roles. New Phytol 1-17

Rukachaisirikul V, Sommart U, Phongpaichit S, Sakayaroj J, Kirtikar K. 2007. Metabolites from the endophytic fungus Phomopsis sp. PSUD15. Phytochemistry 9: 783-787

Schmid E, Oberwinkler F. 1993. Biology and chemistry of endophytes. New Phytol 124: 69.

Schulz B, Boyle C, Draeger S, Römmert AK, Krohn K. 2002. Endophytic fungi: a source of novel biologically active secondary metabolites. 
Mycology Res 106: 996-1004.

Schwarz M, Köpcke B, Weber RWS, Sterner O, Anke H. 2004. 3Hydroxypropionic acid as a nematicidal principle in endophytic fungi. Phytochemistry 65: 2239-2245.

Seifried HE, Anderson DE, Fisher EI, Milner JA. 2007. A review of the interaction among dietary antioxidants and reactive oxygen species. J Nutr Biochem 18: 567-579.

Sette LD, Passarini MRZ, Delarmelina C, Salati F, Duarte MCT. 2006. Molecular characterization and antimicrobial activity of endophytic fungi from coffee plants. J Microbiol Biotech 22: 1185-1195.

Shipunov A, Newcombe G, Raghavendra AKH, Anderson CL. 2008 Hidden diversity of endophytic fungi in an invasive plant. Am J Bot 95 (9): 1096-1108.

Shweta S, Zuehlke S, Ramesha BT, Priti V, Mohana Kumar P, Ravikanth G, Spiteller M, Vasudeva R, Uma Shaanker R. 2010. Endophytic fungal strains of Fusarium solani, from Apodytes dimidiata E. Mey. ex Arn (Icacinaceae) produce camptothecin, 10-hydroxycamptothecin and 9-methoxycamptothecin. Phytochemistry 71 (1): 117-122.

Siegel MR, Latch CM, Bush LP, Fannin FF, Rowan DD, Tapper BA, Bacon CW, Johnson MC. 1990. Biology and chemistry of endophytes. J Chem Ecol 16: 3301.

Singh A, Singh A, Kumari M, Rai MK, Varma A. 2003. Importance of Piriformospora indica-A novel symbiotic mycorrhiza-like fungus: an overview. Ind J Biotechnol 2: 65-75.

Smith SA, Tank DC, et al. 2008. Bioactive endophytes warrant intensified exploration and conservation. PLoS One 3 (8): e3052.

Song YC, Huang WY, Sun C, Wang FW, Tan RX. 2005. Characterization of graphislactone $\mathrm{A}$ as the antioxidant and free radical-scavenging substance from the culture of Cephalosporium sp. IFB-E001, an endophytic fungus in Trachelospermum jasminoides," Biol Pharm Bull 28: 506-509.

Srinivasan K, Jagadish LK, Shenbhagaraman R, Muthumary J. 2010 Antioxidant activity of endophytic fungus Phyllosticta sp. isolated from Guazuma tomentosa. J Phytol 2 (6): 37-41

Stierle A, Strobel G, Stierle D. 1993. Taxol and taxane production by Taxomyces andreanae, an endophytic fungus of Pacific yew. Science 260: 214-216.

Strobel G. 2006. Muscodor albus and its biological promise. J Ind Microb Biotech 33: 514-522.

Strobel G, Daisy B. 2003. Bioprospecting for microbial endophytes and their natural products. Microbiol Mol Biol Rev 67: 491-502.

Strobel G, Ford E, Worapong J et al.. 2002. Isopestacin, an isobenzofuranone from Pestalotiopsis microspora, possessing antifungal and antioxidant activities. Phytochemistry, 60: 179-183, 2002.

Strobel GA, Kluck K, Hess WM, Sears J, Ezra D, Vargas PN. 2007. Muscodor albus E-6, an endophyte of Guazuma ulmifolia making volatile antibiotics: isolation, characterization and experimental establishment in the host plant. Microbiology 153: 2613-2620.

Sugawara K, Ohkubo H, Yamashita M, Mikoshiba Y. 2004. Flowers for Neotyphodium endophytes detection: a new observation method using flowers of host grasses. Mycoscience 45: 222-226.

Sumarah MW, Puniani E, Sørensen D, Blackwell BA, Miller JD. 2010 Secondary metabolites from anti-insect extracts of endophytic fungi isolated from Picea rubens. Phytochemistry 71 (7): 760-765.

Sun C, Johnson JM, Cai D, Sherameti I, Oelmüller R, Lou B. 2010 Piriformospora indica confers drought tolerance in Chinese cabbage leaves by stimulating antioxidant enzymes, the expression of droughtrelated genes and the plastid-localized CAS protein. J Plant Physio 167 (12): 1009-17.

Surette MV, Sturz VA. 2003. Biology and chemistry of endophytes. Plant Soil 253: 381 .

Suryanarayanan TS, Thennarasan S. 2004. Temporal variation in endophyte assemblages of Plumeria rubra leaves. Fun Div 15: $197-$ 204.

Suryanarayanan TS, Wittlinger SK, Faeth SH. 2005. Endophytic fungi associated with cacti in Arizona. Mycol Res 109 (5): 635-639

Tan RX, Zou WX. 2001. Endophytes: a rich source of functional metabolites. Nat Prod Rep 18: 448-459.

Tejesvi MV, Nalini MS, Mahesh B, Prakash HS, Kini KR, Shetty HS, Ven S. 2007. New hopes from endophytic fungal secondary metabolites. Bol Soc Quím Méx 1 (1): 19-26

Uma SR, Ramesha BT, Ravikanth G, Rajesh PG, Vasudeva R, Ganeshaiah KN. 2008. Chemical profiling of $N$. nimmoniana for camptothecin, an important anticancer alkaloid: towards the development of a sustainable production system. In: Ramawat KG,
Merillion J (eds) Bioactive molecules and medicinal plants. Springer, Berlin.

Uwe D, Helmut B, Philipp F. 2007. Piriformospora indica promotes adventitious root formation in cuttings. Sci Hort 112 (4): 422-426.

Valko M, Leibfritz D, Moncol J, Cronin MTD, Mazur M, Telser J. 2007. Free radicals and antioxidants in normal physiological functions and human disease. Inter J Biochem Cell Bio 39: 44-84.

Vanessa MC, Christopher MMF. 2004. Analysis of the Endophytic Actinobacterial Population in the Roots of Wheat (Triticum aestivum L) by Terminal Restriction Fragment Length Polymorphism and Sequencing of 16S rRNA Clones. Appl Envr Microbiol 70: 317871794.

Varma S, Varma A, Rexer KH, Hasse G, Kost A, Sarbhoy P, Bisen B, Bütehorn, Franken P. 1998. Piriformospora indica, gen. et sp. nov., a new root-colonizing fungus. Mycologia 90: 898-905.

Vennila R, Thirunavukkarasu SV, Muthumary J. 2010. Evaluation of fungal taxol isolated from an endophytic fungus Pestalotiopsis pauciseta AVM1 against experimentally induced breast cancer in Sprague Dawley rats. Res J Pharmacol 4 (2): 38-44.

Verma VC, Kharwar RN. 2006. Efficacy of neem leaf extract against its own fungal endophyte Curvularia lunata. J Agri Technol 2 (2): 329. 335.

Wagenaar MM, Corwin J, Strobel G, Clardy J. 2000. Three new cytochalasins produced by an endophytic fungus in the genus Rhinocladiella. J Natl Prod 63 (12): 1692-1695.

Wall ME, Wani MC, Cook CE, Palmer KH, McPhail AT, Sim GA. 1966. Plant antitumor agents. I. The isolation and structure of camptothecin, novel alkaloidal leukemia and tumor inhibitor from Camptotheca acuminate. J Ame Chem Soc 88: 3888-3890.

Weber RWS, Stenger E, Meffert A, Hahn M. 2004. Brefeldin A production by Phoma medicaginis in dead pre-colonized plant tissue: a strategy for resource conquest? Mycol Res 108 (6): 662-671.

Wei1 J, Xu T, Guo L, Liu, A, Zhang Y, Pan X. 2009. Endophytic Pestalotiopsis species associated with plants of Podocarpaceae, Theaceae, and Taxaceae in southern China. Fun Div 24: 55-74

Wilkinson HH, Siegel MR, Blankenship JD, Mallory AC, Bush LP, Schardl CL. 2000. Biology and chemistry of endophytes. Mol Plant Microbe Interact 13: 1027.

Wiyakrutta S, Sriubolmas N, Panphut W, Thongon N, Danwisetkanjana K, Ruangrungsi N, Meevootisom V. 2004. Endophytic fungi with anti-microbial, anti-cancer and anti-malarial activities isolated from Thai medicinal plants. World J Microbiol Biotech 20: 265-272.

Worapong J, Ford E, Strobel G, Hess W. 2002. UV light-induced conversion of Pestalotiopsis microspora to biotypes with multiple conidial forms. Fun Div 9: 179-193.

Yadav V, Kumar M, Deep DK, Kumar H, Sharma R, Tripathi T, Tuteja N, Saxena AK, Johri AK. 2010. A phosphate transporter from the root endophytic fungus Piriformospora indica plays a role in phosphate transport to the host plant. J Biol Chem 85 (34): 26532-44

Lv YL, Zhang FS, Chen J, Cui JL, Xing YM, Li XD, Guo SX. 2010. Diversity and antimicrobial activity of endophytic fungi associated with the alpine plant Saussurea involucrata. Biol Pharm Bull 33 (8): 1300-1306.

Yan H, Gao S, Li C, Li X, Wang B. 2010. Chemical constituents of a marine-Derived Endophytic Fungus Penicillium commune G2M. Molecules 15: 3270-3275

Yang RY, Li CY, Lin YC, Peng GT, She ZG, Zhou SN. 2006. Lactones from a brown alga endophytic fungus (No. ZZF36) from the South China sea and their antimicrobial activities. Bioorg Med Chem Lett 16: 4205-4208

Yang X, Strobel G, Stierle A, Hess WM, Lee J, Clardy J. 1994. A fungal endophyte-tree relationship: Phoma sp. in Taxus wallachiana. Plant Sci 102: 1-9.

Zhang HW, Song YC, Tan RX. 2006. Biology and chemistry of endophytes. Natl Prod Rep 23: 753-771.

Zhang JY, Tao LY, Liang YJ, et al.. 2009. Secalonic acid D induced leukemia cell apoptosis and cell cycle arrest of G1 with involvement of GSK-3 $\beta / \beta$-catenin/c-Myc pathway. Cell Cycle 8: 2444-2450.

Zhao J, Mou Y, Shan T, Li Y, Zhou L, Wang M, Wang J. 2010. Antimicrobial Metabolites from the endophytic fungus Pichia guilliermondii isolated from Paris polyphylla var. yunnanensis. Molecules 15 (11): 7961-7970

Zhou X, Zhu H, Liu L, Lin J, Tang K. 2010. A review: recent advances and future prospects of taxol-producing endophytic fungi. Chem Matl Sci 86 (6): 1707-1717. 